Nutr. Dieta 1964;6:I-IV

\title{
Contents, Vol. 6, 1964
}

Nutritio et Dieta

Europäische Zeitschrift für Ernährung und Diätetik

European Review of Nutrition and Dietetics

Revue européenne de nutrition et de diététique

EDITORES

E, J. BIGWOOD, Bruxelles J.

H. H. BERG, Hamburg J.

R. BOLLER, Wien F.

E. LE BRETON, Paris A.

L. BRULL, Liège H.

F. S. P. VAN BUCHEM, Haarlem A.

M. COPPO, Modena R.

H. D. CREMER, Giessen G.

CH. DARNATJD, Toulouse $\mathrm{H}$.

J. DEL·FOSSE, Bruxelles T.

M. DEMOLE, Geneve G.

M. J. L. DOLS, Wassenaar A.

G. DUCHESNE, Paris H.

H. GLATZEL, Dortmund J.

W. GLOOR-MEYER, Zurich F.

J. GONTZEA, Bucarest L.

H. GOUNELLE, Paris G.

W. HALDEN, Graz G.

C. DEN HARTOG, Den Haag

E.

R. JACQUOT, Paris R.

H. KRAUT, Dortmund

KÜHNAU Hamburg

LEDERER, Louvain

MANCINI, Roma

P. MEIKLEJOHN, Edinburgh

G. MO GEN A, Madrid

MOSSE, Paris

NICOLAYSEN, Oslo

PEQUIGNOT, Paris

SARLES, Marseille

F. S. M. VAN SCHAIK, Den Haag

S. SCHETTLER, Berlin

VAN DER SCHUEREN, Gand

M. SINCLAIR, Oxford 
C. SOMOGYI, Zurich

J. TRAISSAC, Bordeaux

TRAVIA, Roma

P. VECCHI, Modena

VERDONK, Gand

VERZAR, Basel

WENGER, Wien

REDACTORES

E. AZERAD, Paris

J. TREMOLIERES, Paris

H. KAPP, Basel

K. A. J. WRETLIND, Stockholm

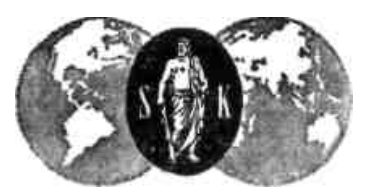

1964

Vol. 6

BASEL (Schweiz)

S. KARGER

NEW YORK

INDEX

Competition Dr. Heinz Karger Memorial Foundation - Preisausschreiben Dr. Heinz-

Karger-Gedächtnis-Stiftung - Concours Fondation Commemorative Dr. Heinz Karger

Babala, J.: vide Simko, V.

Ballester, Digna; Tagle, Maria A. and Donoso, G.: The Effect of Human Growth

Hormone, 17 $\alpha$-methyl-1 7/?-hydroxyandrost-1,4-dien-3one and 1 -methyl-zl '-5 $\alpha$-androsten-

17ß-ol-3-on-17/1̂-acetate on the Net Protein Utilization of a 10\% Casein Diet and on the

Carcass Composition of the Rat. - Wirkung von menschlíchem Wachstumshormon, 17-a-

Methyl-17ß-Hydroxyandrost-1,4-Díen-3one und 1-Methyl- $\triangle$ 'Sa-androsten-17ß-ol-3-on-

17ß-Azetat aufdíe Eiweíßausnützung einer 10\%-Kaseinkost und aufdie Zusammensetzung des evíszeríerten Rattenkörpers. - L'effet de Thormone de croissance humaine de la 17- $\alpha$ méthyl, 17-/?-hydroxyandrost-1,4-dien-3one et de la 1-méthyl-Zl'-5 $\alpha$-androsten-17/?-

ol-3-on-17ß-acétate sur Гutilisation nette protéique dans un regime des calories en

caséine à $10 \%$ et sur la composition de la carcasse chez le rat

171

Bencze, B.: vide Gerloczy, F.

Blumberger, W. und Glatzel, H.: Beiträge zur Physiologie der Gewürze und Würzstoffe.

Die Wirkung von Ingwer auf Speichelmenge und Speichelbeschaffenheit. - The Physio

logy of Spices and Condiments. The Action of Ginger on the Amount and Condition of the

Saliva. - Contributions à la physiologie des épices et aromates. Action de $\Gamma$ lngwer sur la quantité de salive et sa composition 181

Blumberger, W. und Glatzel, H.: Beiträge zur Physiologie der Gewürze und Würzstoffc.

III. Die Wirkungen von Fleischbrühe und Fleischextrakt auf Speichelmenge und Speichelbeschaffenheit. - The Physiological Effects of Spices and Condiments. III. The Effects of Meat Soups and Extracts upon Quantity and Composition of the Saliva. - 
Contributions à la physiologie des épices et aromates. III. L'action des bouillons et extraits de viande sur la quantité de salive et sa composition 248

Blumberger, W. und Glatzel, H.: Beiträge zur Physiologie der Gewürze und Würzstoffe.

IV. Die Speichelwirksamkeit der «Genußsäuren». - Contributions à la physiologie des épices et aromates. IV. Activíté salívaíre des acídes condiments. - The Physiological Effects of Spices and Condiments. IV. Salivary Effects of Acid Flavouring Agents 296

Bucko, A.: vide $3 / 8$ imko, V.

Bucko, A. et Simoncic, R.: L'influence de la nutrition sur revolution des nephrites expérimentales aiguës. - Wirkung der Ernährung auf den Verlauf der experímentellen akuten Nephritis. - The Effects of Diet on the Course of Experimental Acute Nephritis

Ceausi, Gh.: vide Pavel, I.

Chisiu, N.: vide Pavel, I.

Clement, J. et Rigollot, B.: Etude in vitro de quelques activités enzymatiques (lipase, cholestérolestérase et phosphatidase) des sues pancréatique et duodenal humains. In-vitro-Versuche mit einígen Enzymaktívitäten (Lipase, Cholesterinesterase, Phosphat idase) des menschlíchen Pankreas- und Duodenalsaftes. - In Vitro Study of the Activity of Certain Enzymes (Lipase, Cholestérolestérase and Phophatidase) in the Pancreatic Juice 61

Donoso, G.: vide Ballester, Digna.

Droste, H. und Jekat, F.: Nährstoffversorgung in Arbeitnehmer- und Rentnerhaushalten der Bundesrepublik Deutschland während der Zeit von 1950-1962 I. - Nutrition in Workers, and Pensioners'1 Families in the German Federal Republic between 1950 and 1962 I. - L'alimentation dans les families de travailleurs et de pensionnés en République fédérale allemande de 1950 à 1962 I 117

Dupin, H.: vide Richir, $\mathrm{Cl}$.

Ericson, L.-E.: vide Kihlberg, R.

Fábry, P.: vide Hejda, S.

Gerloêzy, F.; Tarján, R. and Bencze, B.: Protein Deficiency Observed in a Pair of Twins Fed Exclusively with Mother's Milk. - Eiweißmangel beí eínem ausschließlich mil Muttermilch ernährten Zwíllíngspaar. - Deficit protéique observe chez une paire de jumeaux nourris exclusivement au lait maternel $\quad 157$ Glatzel, H. und Rettenmaier, G.: Ernährungsphysiologische Brotvergleiche - VI. Bl·utzuckerspiegel und Sättigung. - Comparison of Different Breads in the Physiology of Nutrition - VI. Blood Sugar Levels and Satiation. - Valeur nutritionnelle physiologique comparée de différents pains - VI. Glycémie et satiété

Glatzel, H.: vide Blumbehger, W.

Hallberg, D.: On the Kinetics of the Elimination of Intravenous Fat Emulsion from the Blood Stream in Dog and Man. - Kínetík der Klärung íntravenöser Fetlemulsíonen beím Hund und beím Menschen. - Cinétique de l'élimination des emulsions de graisses perfusées dans les veines du courant sanguin chez le chien et Thomme 237

Hejda, S. and Fábry, P.: Frequency of Food Intake in Relation to Some Parameters of the Nutritional Status. - Häufigkeít der Nahrungsaufnahme in Bezíehung zu eínigen Gegebenheíten des Ernährungszustandes. - Frequence des repas en relation avec quelques paramètres de Tétat nutritionnel 216 
Henane, R.: L'alimentation en zone désertique saharienne. Etude médico-physiologique. Die Ernährung in der Wüstenzone der Sahara. Eíne medízínisch-physiologísche Untersuchung. - Nutrition in the Sahara Desert Area. Medico-Physiological Study

Jekat, F.: vide Droste, $\mathrm{H}$.

Jekat, F.: vide Pabst, W.

Kallistratos, G. und Sengbusch, R. von: Vergleichende Untersuchungen über die Verluste verschiedener Nahrungsmittelbestandteile durch Gefriertrocknung und durch andere Trocknungsarten. - Comparison of the Losses in Various Food Components under Freeze-Dryíng and other Drying Methods. - Recherches comparatives sur les pertes de diverses parties nutritives des aliments par la dessication par le froid et autres moyens de dessication 193

Kihlberg, R. and Ericson, L.-E.: Amino Acid Composition and Supplementation of Teff. - Aminosäurengehalt und dessen Anreicherung ím Teff. - Composition en aminoacides et supplementation du teff (graine de céréale) 151

Kramer, Magdalene: vide Tarján, R.

Martineaud, M. et Thémolières, J.: Mesure de la dépense calorique basale dans Tobésité. - Bestímmung des Grundumsatzes bei Fettsucht. - Measurement of Basal Metabolism in Obesity 77

Martineaud, M. et Trémolières, J.: Mesure de la perspiration insensible et des tempera tures cutanées chez Tobèse dans les conditions basales. - Messung der Perspíratío insensíbílis und der Hauttemperatur beím Fettsüchtigen unter Grundumsatzbedíngungen. Measurement of Unperceived Perspiration and Skin Temperature in Obese Subjects under Baseline Conditions 86

Martineaud, M. et Trémolières, J.: Effet d'une surcharge glucidique sur les échanges respiratoires chez Гobèse. - Wirkung einer Glukosebelastung auf den respíratoríschen Stoffwechsel des Fettsüchtigen. - Effect of Excess Carbohydrate on Respiratory Balance in the Obese 203

Martinaud, M.: vide Richir, $\mathrm{Cl}$.

Ondreicka, R.: vide Simko, V.

Pabst, W.; Jekat, F. und Rolle, Ingrid: Die Ausnutzung von Kohlenhydraten, Fett, Phosphor und Stickstoff in walzengetrockneter Scenedesmus-Substanz ermittelt im Ratten-Bilanzversuch. - The Utilization of Carbohydrates, Fats, Phosphorus and Nitrogen from Roller-dried Scenedesmus Substance as Shown by Balance Studies in the Rat. Utilisation des hydrates de carbone, de la graisse, du phosphore et de Tazote dans Гalgue desséchée Scenedesmus appliquée à des essais de bilan chez le rat 279

Pavel, I.; Chisiu, N.; Ceausi, Gh. et Tãnãsescu, N.: Action des graisses végétales sur Tathérosclérose expérimentale. - Wirkung der vegetatíven Fette auf die experimentelle Atherosklerose. - Effect of Vegetable Fats on Experimental Atherosclerosis 106 273

Rath, R. and Slabochová, Z.: Changes of Body Composition in the Obese Subjected to Different Types of Reducing Regimes. - Anderungen in der Zusam $\tau$ nensetzung des Körpers bei Fettsüchtígen durch verschícdene Abmagerungsdiäten. - Modifications dans la composition du corps chez Tobèse soumis à différents types de regimes amaigrissants

Rettenmaier, G.: vide Glatzel, H.

229 
Richir, Cl. ; Toury, J.; Martineaud, M. et Dupin, H.: Observations sur des accidents de toxicoses fungiques survenus dans des élevages de canetons. - Beobachtungen über Pilztoxíkosen bei der Entenaufzucht. - Observations on Fungal Intoxications in Ducklings

Rigollot, B.: vide Clement, J.

Rolle, Ingrid: vide Pabst, W.

Sengbusch, R. von: vide Kallistratos, G.

91

§imko, V.; Bucko, A.; Babala, J. and Ondreicka, R.: Chemical and Physical Changes

Induced in Food Fats During the Process of Heating and Their Effect on the Histological Picture of Guinea-pig Organs. - Durch den Erhítzungsprozess hervorgerufene chemísche und physíkalísche Veränderungen von Nahrungsfetten und deren Eínfluß auf das histologísche Bíld von Organen des Meerschweinchens. - Modifications physiques et chimiques provoquées par le chauffage des graisses alimentaires et leur effet sur Гaspect histologique des organes du cobaye

§imoncic, R.: vide Bucko, A.

Slabochová, Z.: vide Rath, R.

Tagle, Maria A.: vide Ballester, Digna.

Tånäsescu, $\mathrm{N} \cdot$ : vide Pavel, I.

263

Tarján, R. and Kramer, Magdalene: Effect of Dietary Fats on the Cholesterol and Carotene Metabolism. - Wirkung des Nahrungsfettes auf den Cholesterín- und Karotínstoffwechsel. - Action des graisses alimentaires sous le cholesterol et le métabolisme de carotene

Tarján, R.: vide Gerloczy, F.

Toury, J.: vide Richir, Cl.

Travia, L.: Correlative Variations of Total Lipemia, Total Cholesterolemia and the Beta/ Alpha Lipoprotein Ratio in Humans of Excess Weight Due to Hypernutrition. - Beziehungen der Variationen des Serumgehaltes an Gesamtfett, Gesamtcholesterin, Beta/AlphaLipoproteinindex bei Menschen mil Übergewicht infolge Überfülterung. - Relations entre les variations de la lipémie totale, de la cholestérolémie totale et du rapport beta/alpha lipoprotéines chez les obèses par hypernutrition 21

Travia, L.: Correlated Variations of the Total Lipemia, Cholesterolemia, Beta/Alpha Lipoprotein Ratio and Oral Glucose Tolerance Test. - Korrelatíonsänderungen von Lípämíe, Cholesterinämíe, BetalAlpha-Lípoprotein-Relation und oralem Glukose-ToleranzTest. - Relations entre les variations de la lipémie totale, de la cholestérolémie, du rapport beta/alpha lipoprotéines et le test de tolerance par voie orale 207 Trémolières, B.: vide Martineaud, M.

Buchbesprechungen - Book Reviews - Livres nouveaux 156, 234

Lettre à l'éditeur $\quad 76$

Alle Rechte. insbesonde $\Gamma$ e das der Übersetzıng in fremde Sprachen, vorbehalten.

Ohne atısdrückliehe Genehraigung des Verlages ist es auch nicht gestattet, diesen Band Oder

Teile

daraus auf photomeohanischem Wpge (Photokopie, Mikrokopie) zu vei”vielfältigen.

CD

Copyright 1964 by S. Karger AG, Basel

Printed in Switzerland 
Cliches: Aberegg-Sterner \& Cie., AG, Bern und Steiner \& Cie., AG, Basel Druck: Lüdin AG, Ließtal 